\title{
Analisis Tingkat Kepuasan Pelanggan Terhadap Kelolaan Mesin ATM
}

\author{
Wisnu Rinaldi \\ Program Studi Magister Manajemen, Universitas Muhammadiyah Sumatera Utara Medan, Indonesia \\ Jl. Denai No. 217, Tegal Sari Mandala II, Medan Denai, Kota Medan, Sumatera Utara 20371 \\ Email: aldi_ssi@yahoo.co.id
}

\begin{abstract}
Abstrak. Penelitian ini bertujuan untuk mengetahui persepsi pelanggan dan menganalisa harapan pelanggan untuk menjaga tingkat layanan dari PT. Swadharma Sarana Informatika Medan sehingga kepuasan dari pelanggan terhadap layanan Mesin ATM yang di kelola bisa membuahkan hasil yang baik. Metode analisis data yang digunakan adalah deskriptif kuantitatif Sampel yang digunakan adalah sampel jenuh dimana populasi penelitian sebanyak 24 orang dari 5 perusahaan pelanggan yaitu bank Mandiri, bank BNI, bank BRI, bank Mega dan bank HSBC. Kualitas layanan dibagi dalam 5 dimensi dan 25 indikator, untuk mengukur dimensi dan indikator digunakan uji validitas dan uji reliabilitas. Dari 5 dimensi kualitas layanan yang di uji yaitu kenyataan, keandalan, daya tanggap, jaminan, dan kepedulian, menghasilkan Kudran I prioritas utama adalah kenyataan dimana tingkat ketersediaan pegawai ahli dan ketersediaan spare part menjadi prioritas utama yang harus dipertahankan. Untuk kuadran II yang perlu di jaga adalah daya tanggap dimana respon dalam penanganan penyelesaian problem harus lebih cepat dan dari sisi dimensi kehandalan, jam operasional kantor 24 jam menjadi persepsi yang baik yang harus tetap dijaga. Kuadran III merupakan dimensi jaminan dimana pencapaian target service level agreement terus di tingkatkan untuk perbaikan kinerja. Dan kuadran IV di mensi empati harus dilakukan perbaikan dan peningkatan untuk menghasilkan kepuasan pelanggan yang lebih baik.
\end{abstract}

Kata kunci: Kenyataan, Keandalan, Daya Tanggap, Jaminan, Kepedulian

\begin{abstract}
This study aims to determine customer perceptions and analyze customer expectations to maintain the level of service from PT. Swadharma Sarana Informatika Medan so that customer satisfaction with ATM machine services that are managed can produce good results. The data analysis method used is quantitative descriptive. The sample used is a saturated sample in which the study population is 24 people from 5 customer companies, namely Mandiri banks, BNI banks, BRI banks, Mega banks and HSBC banks. Service quality is divided into 5 dimensions and 25 indicators, to measure the dimensions and indicators used validity and reliability tests. Of the 5 service quality dimensions tested, namely reality, reliability, responsiveness, assurance, and concern, making Kudran I a top priority is the fact that the availability of skilled personnel and the availability of spare parts are the main priorities that must be maintained. For quadrant II that needs to be guarded is responsiveness where the response in handling problem solving must be faster and in terms of reliability dimensions, 24-hour office hours are a good perception that must be maintained. Quadrant III is a guarantee dimension where the achievement of the target service level agreement continues to be increased to improve performance. And quadrant IV in Mensi empathy must be improved and improved to produce better customer satisfaction
\end{abstract}

Keywords : reality, reliability, responsiveness, assurance and concern.

\section{PENDAHULUAN}

Menghadapi arus globalisasi dengan tingkat persaingan yang semakin tajam baik berskala nasional maupun internasional, perlu kiranya menjadi perhatian khusus para pengusaha dalam menjaga keberlangsungan perusahaan. Kompetitor akan selalu berusaha dengan sekuat tenaga untuk memenuhi keinginan konsumen, dimana salah satu fokusnya adalah bagaimana mereka berusaha agar produknya (baik barang maupun jasa) lebih unggul dari produk pesaing. Perusahaan jasa seperti layanan pengisian mesin ATM, lembaga 
pendidikan dan lain sebagainya, kompetitor dalam meraih minat konsumen dalam membeli produk jasa yang ditawarkan lebih ditekankan terhadap kepuasan layanan pelanggan. Sebagai perusahaan pelayanan publik dalam memberikan pelayanan kepada pelanggan harus memperhatikan kebutuhan dan keinginan pelanggan guna memberikan nilai kepuasan kepada pelanggan. Oleh karena itu dituntut adanya persaingan yaitu berupa jasa pelayanan. Melalui sistem administrasi maupun operasional yang lebih baik.

Perbankan sebagai lembaga yang berperan dalam transaksi keuangan telah menggunakan teknologi informasi yang terus mengalami perkembangan. Masyarakat menyimpan uang di bank, maka pihak perbankan memberikan rangsangan berupa balas jasa yang akan diberikan kepada para nasabah. Rangsangan tersebut dapat berupa kemudahan bertransaksi 24 jam baik tunai, setor uang maupun non tunai dengan fasilatas pembayaran telephon, PLN dan lain-lain, gratis biaya transfer antar rekening.

Kualitas layanan adalah tingkat keunggulan yang diharapkan dan pengendalian atas tingkat keunggulan tersebut untuk memenuhi keinginan pelanggan, dalam kualitas pelayanan ada beberapa dimensi yaitu tangible (bukti fisik), reability (keandalan), responsive (daya tanggap), Assurance (jaminan), dan emphaty (empati). Fasilatas mesin ATM yang tersebar diseluruh Indonesia, yang memudahkan nasabah dalam mengambil dan menyetor setiap harinya tampa dibatasi ruang dan waktu. Kemudahan yang diberikan melalui layanan ATM menjadi daya tarik tersendiri bagi nasabah, kualitas pelayanan tercermin dari kepuasan konsumen. Percepatan penanganan problem mesin ATM sangat mempengaruhi kulitas layanan, ada beberapa faktor yang menyebabkan terjadikan kerusakan pada mesin ATM yaitu Uang sangkut (cash handler fatal error), Kartu sangkut (card reader fatal error), kertas struk sangkut (receipt fatal error), dan jaringan komunikasi terputus. Pengisian ATM (Cash Replenisment) harus mengunakan pengaman yang bersenjata api, ini merupakan syarat utama dari pemberi kerja untuk mengurangi resiko terjadinya tindakan perampokan ataupun kecurangan pegawai dalam melaksanakan pekerjaannya. Tanggung jawab yang besar yang diberikan perusahaan kepada pegawai harus di dukung dengan standar pengamanan yang memadai.

Tjiptono \& Chandra (2012) mendefenisikan kualitas layanan sebagai seberapa jauh perbedaan antara kenyataan dengan harapan para nasabah atas layanan yang mereka terima. Unsur utama dalam kualitas jasa yaitu expected service dan perceived service. Apabila jasa yang diterima atau yang dirasakan sesuai dengan yang diharapkan, maka kualitas jasa yang dipersepsikan sebagai kualitas yang baik dan memuaskan. Jika jasa yang diterima melampaui harapan nasabah. Maka kualitas jasa yang dipersepsikan sebagai kualitas yang ideal. Sebaliknya jika kualitas jasa yang diterima lebih rendah daripada yang diharapkan, maka kualitas jasa akan dipersepsikan buruk atau tidak memuaskan.

Lembaga keuangan yang sangat bergantung pada kepercayaan masyarakat, Mesin ATM sebagai image dari bank dituntut memberikan pelayanan yang optimal dengan selalu mengutamakan kualitas pelayanan sehingga nasabah akan merasa puas dan aman dalam bertransaksi. Lingkungan yang berubah sangat cepat dalam hal peraturan, struktur, dan teknologi telah merubah fungsi dari mesin ATM yang biasanya hanya untuk menarik uang akan tetapi sekarang sudah ada mesin ATM setor uang. Perubahan-perubahan yang terjadi telah mengurangi hambatan-hambatan nasabah dalam bertransaksi yang bisa dilakukan malam hari baik setor uang maupun tarik uang. Ekspansi tersebut memberikan nilai posistif sehingga kondisi tersebut akan menciptakan pasar industri perbankan global yang terintegrasi. Perubahan-perubahan tersebut memungkinkan persaingan yang cukup tinggi di perusahaan perusahaan pengisian uang ATM sehingga perluasan pelayanan yang diberikan kepada nasabah-nasabahnya dan menjadikan makin kompetitif satu sama lain. 
Menjadi suatu keharusan bagi perusahaan untuk selalu berusaha menjaga agar bagaimana pelanggan merasa puas dengan pelayanan dan produk yang diberikan, dengan tidak selalu berorientasi pada profit semata. Perwujudan pengorbanan yang dilakukan oleh pelanggan sejalan dengan proses pertukaran adalah biaya transaksi, dan resiko untuk mendapatkan produk jasa yang ditawarkan. Nilai pelanggan merupakan salah satu konsep pemasaran.

Menurut Soetanto Hadinoto, bankir yang berkarier di BRI selama 32 tahun, pertama kali ATM dikembangkan karena munculnya kebutuhan alternatif transaksi selain di kantor cabang bank. Namun, nasabah ragu-ragu menggunakannya. Sebab, tidak mudah membangkitkan kepercayaan nasabah pada ATM sebagai perwakilan bank dalam membantunya bertransaksi. Belum lagi soal pemakaian mesin ATM itu sendiri. "Aman atau tidak? bisa keluar dengan jumlah persis seperti yang diminta? uang di rekening berkurangkah tanpa diminta? Banyak pihak belum melirik keandalan mesin ini. Bahkan ada pula yang mencemooh," tulis Soetanto dalam Bank Strategy on Funding and Liability Management (Isnaeni, 2019). Setelah Bank Niaga, Bank BCA menyediakan ATM pada 1988, disusul bank-bank lain. "Nasabah baru terbiasa menggunakan ATM sekitar 10 tahun kemudian. Diperlukan edukasi nasabah yang terus menerus," tulis Soetanto. Pada saat itulah ATM berkembang pesat. Mesin kasir otomatis ini dengan mudah dapat ditemui di mana-mana. Jaringannya semakin luas. Nasabah semakin akrab dengan ATM. Meski bukan yang pertama menawarkan layanan ATM dan internet banking di Indonesia, BCA adalah bank pertama yang melakukan proses edukasi sistematis dalam pemakaian kedua layanan electronic delivery channel tersebut. Proses edukasi tersebut diimbangi dengan penambahan keberadaan ATM dan fasilitas layanan ATM serta internet banking secara sistematis (Kartajaya, 2009).

Sebagai perusahaan pelayanan publik dalam memberikan pelayanan kepada pelanggan harus memperhatikan kebutuhan dan keinginan pelanggan guna memberikan nilai kepuasan kepada pelanggan. Namun dalam prakteknya, dalam hal kualitas pelayanan masih belum sepenuhnya mampu memuaskan nasabah. Berdasarkan hasil pengamatan dan wawancara yang dilakukan penulis di lapangan terdapat gejala-gejala berkaitan dengan kualitas pelayanan yaitu : Penanganan problem ATM Yang Lambat, banyaknya kompalin selisih uang yang keluar dari mesin ATM, kejujuran pegawai, keamanan dalam melaksanakan pekerjaan, Jaringan online sering mengalami gagal koneksi, dan Layanan ATM yang sering mengalami kegagalan tarik tunai, seperti uang tidak keluar sehingga nasabah yang ingin melakukan transaksi terhambat oleh kendala tersebut.

\section{LANDASAN TEORI}

\section{Kualitas Pelayanan}

Menurut Kotler (2009) kualitas adalah totalitas fitur dan karakteristik produk atau jasa yang bergantung pada kemampuannya untuk memuaskan kebutuhan yang dinyatakan atau tersirat. Ini jelas merupakan defenisi yang berpusat pada pelanggan. Perusahaan yang memuaskan sebagian besar kebutuhan pelanggannya sepanjang waktu disebut perusahaan berkualitas. Pelayanan merupakan kegiatan yang tidak dapat didefinisikan secara tersendiri yang pada hakekatanya bersifat intangible (tidak teraba), yang merupakan pemenuhan kebutuhan dan tidak harus terikat pada penjualan produk atau pelayanan lain (Radiman, Gunawan, Wahyuni, \& Jufrizen, 2018). Menurut Jasfar \& Kristaung (2012), kualitas Layanan adalah bagaimana tanggapan konsumen terhadap pelayanan yang dikonsumsi atau yang dirasakan. Sedangkan menurut Lupiyoadi \& Hamdani (2006) mengatakan jika kenyataannya sama atau lebih dari yang diharapkan maka layanan dapat dikatakan berkualitas atau 
memuaskan, sebaliknya jika kenyataan kurang dari yang diharapkan maka layanan dapat dikatakan tidak berkualitas atau memuaskan.

Sangadji \& Sopiah (2013) mengatakan lima dimensi kualitas jasa, yaitu : 1) kenyataan (tangibles) tersedianya fasilitas fisik, perlengkapan dan sarana komunikasi, dan lain-lain yang bisa dan harus ada dalam proses jasa, 2) keandalan (reliability) yaitu kemampuan untuk memberikan pelayanan yang dijanjikan dengan tepat dan kemampuan untuk dipercaya, terutama memberikan jasa secara tepat waktu, dengan cara yang sama sesuai jadwal yang telah dijanjikan, dan tanpa melakukan kesalahan, 3) daya tanggap (responsiveness) yaitu kemauan atau keinginan para karyawan untuk membantu memberikan jasa yang dibutuhkan konsumen, 4) jaminan (assurance) meliputi pengetahuan, kemampuan, keramahan, kesopanan, dan sifat dipercaya dari kontak personal untuk menghilangkan sifat keragu-raguan konsumen dan membuat mereka merasa terbebas dari bahaya dan resiko, dan 5) empati (empathy) yang meliputi sikap kontak personal atau perusahaan untuk memahami kebutuhan dan kesulitan, konsumen, komunikasi yang baik, perhatian pribadi, dan kemudahan untuk melakukan komunikasi atau hubungan.

\section{Harapan Pelanggan}

Menurut Lovelock \& Wright (2010) harapan pelanggan merupakan satandarinternal yang digunakan pelanggan untuk menilai kualitas suatu pengalaman jasa ataukeyakinan pelanggan sebelum mencoba atau membeli suatu produk, yang dijadikan standaratau acuan dalam menilai kinerja produk tersebut. Meskipun demikian, dalam beberapa halbelum tercapai kesepakatan, misalnya sifat standar harapan yang spesifik, jumlah standaryang digunakan, maupun sumber harapan. Tjiptono \& Chandra (2011) menyatakan bahwa dalam konteks kualitas produk (barang dan jasa) dan kepuasan pelanggan, telah dicapai konsensus bahwa harapan pelanggan mamainkan peran penting sebagai standar perbandingan dalam mengevaluasi kualitas maupun kepuasan. Ekspektasi pelanggan merupakan keyakinan pelanggan sebelum mencoba atau membeli suatu produk, yang dijadikan standar atau acuan dalam menilai kinerja produk bersangkutan. Kendati demikian, konseptualisasi dan operasionalisasi harapan pelanggan masih menjadi isu kontroversial, terutama menyangkut karakteristik standar ekspektasi spesifik, jumlah standar yang digunakan dan sumber ekspektasi. Setiap konsumen mungkin saja memiliki beberapa ekspektasi pra konsumsi yang berbeda, selain itu konsumen yang berbeda bisa pula menerapkan tipe ekspektasi yang berbeda untuk situasi yang berbeda.

Dari uraian diatas, dapat disimpulkan bahwa pelanggan akan memperhatikan elemenelemen yang akhirnya akan membawa mereka pada kepuasan ketika menggunakan jasa yang ditawarkan perusahaan. Dan apabila pelayanan terhadap konsumen tidak atau kurang memuaskan maka akan merasa kecewa dan kemungkinan akan pindah ke produk atau ke perusahaan lain. Pada penelitian ditentukan empat indikator dari variabel harapan pelanggan menurut Mulyani (2003) yaitu : 1) Personal Need / kebutuhan pribadi 2) Explicit Services Promises / janji pelayanan secara eksplisit 3) Implicit Service Promises / janji pelayanan secara implisit 4) Pengalaman masa lampau.

\section{Kepuasan Konsumen}

Pelanggan adalah kata kunci bagi kesuksesan perusahaan. Peran yang demikian penting telah memaksa setiap perusahaan berupaya untuk menyusun kiat atau strategi untuk menarik mereka, sehingga mereka menjadi pembeli produknya (Gultom \& Jufrizen, 2016). Johnson and Fornell (1991) menyatakan bahwa kepuasan konsumen merupakan hasil evaluasi menyeluruh konsumen atas kinerja produk yang dikonsumsinya (Azhar, Jufrizen, Prayogi, \& Sari, 2018). Menurut Kotler \& Amstrong (2012), bahwa perasaan senang atau kecewa seseorang yang 
muncul setelah membandingkan antara persepsi atau respon terhadap kinerja hasil dari produk yang diharapkan. Yi (1991) mengidentifikasi dua konsep kepuasan konsumen yang berbeda yaitu transaction-specific satisfaction dan overall satisfaction. Transac-tion-specific satisfaction merupakan konsep yang merujuk kepada penilaian kepuasan konsumen setelah melakukan pembelian produk atau merek tertentu. Sementara overall satisfaction adalah konsep yang mengukur kepuasan (ketidakpuasan) konsumen terhadap produk atau merek tertentu secara menyeluruh berdasarkan seluruh pengalamannya dalam mengkonsumsi produk atau merek tersebut (Azhar \& Jufrizen, 2017). Menurut Wilkie dalam (Tjiptono, 2006) mendefinisikan kepuasan sebagai suatu tanggapan emosional pada evaluasi terhadap pengalaman konsumsi suatu produk atau jasa. Memberikan arti dari kepuasan konsumen yaitu tingkat perasaan seseorang setelah membandingkan performansi (atau hasil) yang ia rasakan dibandingkan dengan harapannya. Jadi tingkat kepuasan merupakan fungsi dari perbedaan antara kinerja yang dirasakan dengan harapannya. Apabila kinerja dibawah harapan, maka konsumen akan kecewa. Bila kinerja sesuai dengan harapan, konsumen akan puas. Sedangkan bila kinerja melebihi harapan, konsumen akan sangat puas. Harapan konsumen dapat dibentuk oleh pengalaman masa lampau, komentar dari kerabatnya serta janji dan informasi pemasar dan saingannya. Konsumen yang puas akan setia lebih lama, kurang sensitif terhadap harga dan memberi komentar yang baiktentang perusahaan. Dimensi pengukuran kepuasan menurut (Parasuraman, Zeithaml, \& Berry, 1988), dalam melayani konsumen adalah: 1) responsiveness (ketanggapan), yaitu kemampuan untuk menolong pelanggan dan ketersediaan untuk melayani pelanggan dengan baik, 2) reliability (keandalan), yaitu kemampuan untukmelakukan pelayanan sesuai yang dijanjikan dengan segera, akurat dan memuaskan, 3) emphaty (empati) yaitu rasa peduli untuk memberikan perhatian secara individual kepada pelanggan, memahami kebutuhan pelanggan, serta pengetahuan untuk dihubungi, 4) asurance (jaminan), yaitu pengetahuan, kesopanan petugas serta sifatnya yang dapat dipercaya sehingga pelanggan terbebas dari resiko, dan 5) tangibles (bukti langsung), meliputi fasilitas fisik, perlengkapan karyawan, dan sarana komunikasi. Kotler \& Amstrong (2012) yang menyatakan kunci untuk mempertahankan pelanggan adalah kepuasan pelanggan. Dimana Pelanggan yang merasa puas akan melakukan karakter sebagai berikut: 1) melakukan pembelian ulang, 2) mengatakan hal yang baik tentang perusahaan kepada orang lain (rekomendasi), 3) kurang memperhatikan merek dan iklan produk pesaing, dan 4) membeli produk lain dari perusahaan yang sama.

\section{METODOLOGI PENELITIAN}

Pendekatan penelitian yang digunakan penulis adalah dengan melakukan pendekatan deskriptif kuantitatif. Dalam hal ini yang menjadi populasi dalam penelitian ini adalah nasabah pemberi kerja dengan jumlah 24 orang yang terdiri dari 5 orang dari bank BNI, 5 orang dari bank Mandiri, 4 orang dari bank BRI, 5 orang dari bank Mega \& 5 orang dari bank HSBC. Adapun sampel yang digunakan merupakan sampel jenuh yang berjumlah 24 orang. Adapun teknik pengumpulan data yang digunakan adalah melalui pengamatan dan wawancara. Adapun pengujian yang dilakukan dengan metode Importance Analysis (IPA). Dengan mencari tingkat kesesuaian (dengan analisis IPA ) dan diagram kartesius.

\section{HASIL DAN PEMBAHASAN PENELITIAN}

Teknik analisis data yang digunakan untuk mengukur tingkat kepuasaan atas kualitas pelayanan mesin ATM yang dikelola PT. SSI MEDAN adalah teknik analisis importance performance. Dengan hasil tingkat kesesuaian berdasarkan 5 dimensi kualitas pelayanan yaitu kenyataan (tangible), kehandalan (reliability), daya tanggap (responsiveness), jaminan (assurance), dan empati (empathy). Dalam indicator tingkat kesesuaian terdapat penilaian 
tingkat kesesuaian untuk menyatakan baik tidaknya suatu dimensi kualitas pelayanan yang diukur, antara lain :

Tabel 1. Penilaian Tingkat Kesesuaian

\begin{tabular}{cc}
\hline Nilai & Keterangan \\
\hline $81 \%-100 \%$ & SangatBaik \\
\hline $66 \%-80 \%$ & Baik \\
\hline $51 \%-65 \%$ & Cukup Baik \\
\hline $35 \%-50 \%$ & Kurang Baik \\
\hline $0 \%-34 \%$ & Sangat Tidak Baik \\
\hline
\end{tabular}

Berikut hasil untuk masing-masing dimensi:

\section{a. Tingkat Kepuasan Konsumen Pada Dimensi Kenyataan (Tangible)}

Dimensi bukti langsung atau yang sering dikenal dengan tangible dalah salah satu factor yang mempengaruhi kepuasan kelolaan mesin ATM PT. SSI Medan dari segi visual (berhubungan dengan lingkungan fisik). Pada saat yang bersamaan aspek tangible ini juga merupakan salah satu sumber yang mempengaruhi harapan pelanggan. Meliputi fasilitas fisik, perlengkapan, keterampilan dan keramahan karyawan. Berikut hasil tingkat kesesuaian kinerja dan harapan pada nasabah PT. SSI MEDAN berdasarkan dimensi bukti langsung yang diambil dari jawaban responden disajikan pada tabel 4.12. Berikut merupakan cara untuk mendapatkan hasil tingkat kesesuaian dimensi bukti langsung sebagai contoh hanya dihitung pada pernyataan nomor 1 .

Diketahui:

$\mathrm{Xi}=77$

$\mathrm{Yi}=88$

Ditanya: Tki (Tingkat Kesesuaian)...?

Dapat dihitung dengan menggunakan rumus:

$$
\begin{gathered}
\mathrm{TKI}=\frac{\mathrm{Xi}}{\mathrm{Yi}} \times 100 \% \\
\mathrm{TKI}=\frac{77}{88} \times 100 \% \\
\mathrm{TKI}=87,5 \%
\end{gathered}
$$

Hasil diatas merupakan hasil perhitungan untuk mencari tingkat kesesuaian Dimensi bukti langsung pada atribut pernyataan no1, untuk menghitung tingkat kesesuaian pada atribut selanjutnya dihitung dengan menggunakan cara yang sama.

Tabel dibawah ini merupakan hasil tingkat kesesuaian dimensi bukti langsung pada atribut penyataan nomor 1sampai dengan nomor 5 .

Tabel 2. Hasil Tingkat Kesesuaian Kenyataan (Tangible)

\begin{tabular}{ccccc} 
No & $\begin{array}{c}\text { Tingkat } \\
\text { Kinerja }(\mathbf{X})\end{array}$ & $\begin{array}{c}\text { Tingkat } \\
\text { Harapan }(\mathbf{Y})\end{array}$ & $\begin{array}{c}\text { Tingkat Kesesuaian } \\
\text { (TK) }(\boldsymbol{\%})\end{array}$ & $\begin{array}{c}\text { Kinerja Kualitas } \\
\text { Pelayanan }\end{array}$ \\
\hline 1 & 77 & 88 & 87,5 & SangatBaik \\
\hline 2 & 73 & 89 & 82,02 & SangatBaik \\
\hline 3 & 75 & 88 & 85,23 & SangatBaik \\
\hline 4 & 73 & 90 & 81,11 & Sangat Baik \\
\hline 5 & 73 & 91 & 80,22 & Sangat Baik \\
\hline
\end{tabular}

Hasil penelitian menunjukan bahwa pada dimensi bukti langsung dengan pernyataan no. 1 (menggunakan tenaga pegawai yang sudah ahli) pada tingkat kinerja mendapatkan bobot 
penilaian sebesar 77 dari jumlah 24 responden, tingkat harapan mendapatkan bobot penilaian sebesar 88 dari total 24 responden, sehingga menghasilkan tingkat kesesuaian sebesar 87,5\% yang artinya kinerja kualitas pelayanannya sangat baik sesuai dengan harapan pelanggan yang memunculkan tingkat kepuasan pada pelanggan, karena berada pada rentang angka $81 \%$ $-100 \%$. Dimensi kualitas pelayanan no.2 (ketersediaan spare part) pada tingkat kinerja mendapatkan bobot penilaian sebesar 73 dari jumlah responden sebanyak 24, sedangkan pada tingkat harapannya sebesar 89 dari total 24 responden, tingkat kesesuaian yang dihasilnya sebesar $82,02 \%$ yang artinya sangat baik.

Dimensi kualitas pelayanan no.3 (standart sarana prasarana operasional) mendapatkan nilai sebesar 75 pada tingkat kinerja perusahan, tingkat harapan sebesar 88 sehingga menghasilkan nilai pada tingkat kesesuaian sebesar 85,23 yang artinya sangat baik. Dimensi kualitas pelayanan no.4 (keamanan kunci brankas atm) mendapatkan nilai sebesar 73 pada tingkat kinerja perusahan, tingkat harapan sebesar 90 sehingga menghasilkan nilai pada tingkat kesesuaian sebesar 81,11 yang artinya sangat baik. Pernyataan terakhir pada no.5 (kualitas uang di mesin ATM), tingkat kinerja sebesar 73 sedangkan pada harapan sebesar 91 sehingga menghasilkan tingkat kesesuaian sebesar $80,22 \%$ yang artinya sangat baik, karena masih berada di rentang $81 \%-100 \%$.

\section{Tingkat Kepuasan Konsumen Pada Dimensi Keandalan (Reability)}

Dimensi selanjutnya yaitu keandalan. Dimensi ini sering disebut juga dengan reability. Keandalan (reability) adalah kemampuan memberikan pelayanan yang dijanjikan dengan akurat, bebas dari kesalahan dan memuaskan. Berikut merupakan cara untuk mendapatkan hasil tingkat kesesuaian dimensi keandalan sebagai contoh hanya dihitung pada pernyataan nomor 6.

Diketahui:

$$
\begin{aligned}
& \mathrm{Xi}=80 \\
& \mathrm{Yi}=86
\end{aligned}
$$

Ditanya: Tki (Tingkat Kesesuaian)...?

Dapat dihitung dengan menggunakan rumus:

$$
\begin{gathered}
\mathrm{TKI}=\frac{\mathrm{Xi}}{\mathrm{Yi}} \times 100 \% \\
\mathrm{TKI}=\frac{80}{86} \times 100 \% \\
\mathrm{TKI}=93,02 \%
\end{gathered}
$$

Hasil diatas merupakan hasil perhitungan untuk mencari tingkat kesesuaian dimensi keandalan pada atribut pernyataan no 6 , untuk menghitung tingkat kesesuaian pada atribut selanjutnya seperti pada atribut pernyataan nomor $6,7,8,9$ dan 10 dapat dihitung dengan menggunakan cara yang sama.

Berikut hasil tingkat kesesuaian penilaian konsumen terhadap kualitas kinerja pelayanan PT. SSI serta harapan konsumen pada dimensi keandalan yaitu kemampuan untuk memberikan pelayanan yang sesuai dengan janji yang ditawarkan. Penulisakan sajikan pada table 4.13 tentang hasil tingkat kesesuaian pada dimensi keandalan (reability). Berikut merupakan table hasil tingkat kesesuaian pada dimensi keandalan

(reability): 
Tabel 3. Hasil Tingkat Kesesuaian Keandalan (Reability)

\begin{tabular}{ccccc}
\hline No & $\begin{array}{c}\text { Tingkat } \\
\text { Kinerja }(\mathbf{X})\end{array}$ & $\begin{array}{c}\text { Tingkat } \\
\text { Harapan }(\mathbf{Y})\end{array}$ & $\begin{array}{c}\text { Tingkat Kesesuaian } \\
(\mathbf{T K})(\boldsymbol{\%})\end{array}$ & $\begin{array}{c}\text { Kinerja Kualitas } \\
\text { Pelayanan }\end{array}$ \\
\hline 6 & 80 & 86 & 93,02 & Sangat Baik \\
\hline 7 & 80 & 88 & 90,91 & Sangat Baik \\
\hline 8 & 77 & 90 & 85,56 & Sangat Baik \\
\hline 9 & 72 & 86 & 83,72 & Sangat Baik \\
\hline 10 & 78 & 89 & 87,64 & Sangat Baik \\
\hline
\end{tabular}

Hasil yang disajikan pada table diatas memperlihatkan bahwa pada no.6 (Jam kerja operasional kantor 24 jam) tingkat kinerjanya memperoleh nilai sebesar 80 sedangkan pada tingkat harapan sebesar 86 dapat disimpulkan bahwa tingkat kinerja perusahaan lebih rendah dari harapan yang diinginkan oleh pelanggan sehingga memperoleh nilai tingkat kesesuaian sebesar 93,02\% konsumen menilai dalam kinerja kualitas pelayanan ini masih sangat baik.

Dimensi kualitas pelayanan no.7 (memastikan mesin ATM online 24 jam) pada tingkat kinerja memperoleh nilai sebesar 80 dan pada tingkat harapan sebesar 88 menghasilkan tingkat kesesuaian sebesar 90,91\% berarti dapat disimpulkan bahwa kinerja kualitas pelayanan sangat baik karena telah memperoleh nilai di rentang $81 \%-100 \%$.

Berikutnya pada dimensi kualitas pelayanan no.8 (ketepatan dalam menyelesaikan problem atm) pada tingkat kinerja memperoleh hasil sebesar 77 sedangkan pada tingkat harapan memperoleh nilai sebesar 90, tingkat kesesuaian yang dihasilkan sebesar $85,56 \%$, kinerja kualitas pelayanannya termasuk dalam kategori sangat baik.

Lalu pada dimensi kualitas pelayanan no.9 (akurasi dalam proyeksi pengisian mesin ATM), pada tingkat kinerja memperoleh hasil sebesar 72 sedangkan pada tingkat harapan memperoleh nilai sebesar 86, tingkat kesesuaian yang dihasilkan sebesar 83,72\%, kinerja kualitas pelayanannya termasuk dalam kategori sangat baik.

Terakhir dari hasil pernyataan pada dimensi kualitas pelayanan keandalan (reability) menunjukkan hasil dimensi kualitas pelayanan no.10 (kecepatan respon) tingkat kinerja hasilnya sebesar 78 dan tingkat harapan sebesar 89 sehingga memperoleh tingkat kesesuaian sebesar 87,64. Hal ini berarti bahwa kinerja kualitas pelayanannya sangat baik, dikarenakan berada di rentang angka $81 \%-100 \%$.

\section{Tingkat Kepuasan Konsumen Pada Dimensi Daya Tanggap (Responsiveness)}

Dimensi daya tanggap (responsiveness) merupakan kesediaan dan kesigapan para karyawan untuk membantu para pelanggan dan memberikan pelayanan yang cepat dan tanggap, yang meliputi: kesigapan karyawan dalam melayani pelanggan, kecepatan karyawan dalam melayani transaksi dan penanganan keluhan pelanggan. Berikut hasil dari kinerja perusahaan dan harapan konsumen dari kualitas pelayanan PT. SSI Medan.

Sebelumnya penulisakan menjelaskan bagaimana cara untuk mendapatkan tingkat kesesuaian pada dimensi daya tanggap dengan menggunakan contoh pada atribut pernyataan nomor 11.

Diketahui:

$\mathrm{Xi}=77$

$\mathrm{Yi}=88$

Ditanya: Tki (Tingkat Kesesuaian)...?

Dapat dihitung dengan menggunakan rumus:

$$
\mathrm{TKI}=\frac{\mathrm{Xi}}{\mathrm{Yi}} \times 100 \%
$$




$$
\begin{gathered}
\mathrm{TKI}=\frac{77}{88} \times 100 \% \\
\mathrm{TKI}=87,5 \%
\end{gathered}
$$

Hasil diatas merupakan hasil perhitungan untuk mencari tingkat kesesuaian Dimensi daya tanggap pada atribut pernyataan no 11, untuk menghitung tingkat kesesuaian pada atribut selanjutnya seperti pada atribut pernyataan nomor 11, 12, 13, 14 dan 15 dapat dihitung dengan menggunakan cara yang sama. Sehingga akan didapat hasil tingkat kesesuaian pada dimensi daya tanggap seperti pada table 4 dibawah ini.

Tabel 4. Hasil Tingkat Kesesuaian Daya Tanggap (Responsiveness)

\begin{tabular}{ccccc} 
No & $\begin{array}{c}\text { Tingkat } \\
\text { Kinerja (X) }\end{array}$ & $\begin{array}{c}\text { Tingkat } \\
\text { Harapan }(\mathbf{Y})\end{array}$ & $\begin{array}{c}\text { Tingkat Kesesuaian } \\
(\mathbf{T K})(\boldsymbol{\%})\end{array}$ & $\begin{array}{c}\text { Kinerja Kualitas } \\
\text { Pelayanan }\end{array}$ \\
\hline 11 & 77 & 88 & 87,5 & Sangat Baik \\
\hline 12 & 78 & 87 & 89,66 & Sangat Baik \\
\hline 13 & 80 & 90 & 88,89 & Sangat Baik \\
\hline 14 & 78 & 88 & 88,64 & Sangat Baik \\
\hline 15 & 76 & 88 & 86,36 & Sangat Baik \\
\hline
\end{tabular}

Hasil penelitian penulis dari 24 responden yang ada terhadap dimensi daya tanggap (responsiveness) pada PT. SSI Medan dengan pernyataan no 11 (kemampuan dalam penyelesaian masalah yang timbul) tingkat kinerja memperoleh hasil sebesar 77 dan tingkat harapan sebesar 88 sehingga menghasilkan tingkat kesesuaian sebesar 87,5\% yang artinya sangat baik bagi perusahaan.

Kualitas pelayanan no.12 (kemampuan cepat tanggap terhadap keluhan pemberi kerja) pada dimensi daya tanggap hasil tingkat kinerja memperoleh hasil sebesar 78 dan tingkat harapan sebesar 87 sehingga menghasilkan tingkat kesesuaian sebesar 89,66\% yang dinyatakan sangat baik bagi perusahaan.

Pernyataan no.13 (daya tanggap karyawan dalam hal-hal operasional mesin ATM) tingkat kinerjanya sebesar 80 dan tingkat harapannya sebesar 90 menghasilkan tingkat kesesuaian sebesar $88,89 \%$ berarti kinerja perusahaan sangat baik dalam hal ini sehingga konsumen puas karena sesuai dengan harapan yang mereka inginkan.

Pada pernyataan no.14 (kemampuan karyawan berkomunikasi dengan pemberi kerja) tingkat kinerja yang dihasilkan sebesar 78 dan tingkat harapan sebesar 88, menghasilkan tingkat kesesuaian sebesar $88,64 \%$ berarti dalam dimensi ini kinerja perusahaan sudah sangat baik karena berada di rentang $81 \%-100 \%$.

Yang terakhir, pada pernyataan no.15 (kecepatan waktu penyelesaian permasalahan) tingkat kinerja yang dihasilkan sebesar 76 dan tingkat harapan sebesar 88, menghasilkan tingkat kesesuaian sebesar $86,36 \%$ berarti dalam dimensi ini kinerja perusahaan sudah sangat baik karena berada di rentang $81 \%-100 \%$.

\section{Tingkat Kepuasan Konsumen Pada Dimensi Empati (Empathy)}

Empati (empathy) yaitu perhatian secara individual yang diberikan perusahaan kepada pelanggan, seperti kemudahan pelanggan dalam menghubungi perusahaan, kemampuan karyawan dalam berkomunikasi dengan pelanggan dan lain-lain. Untuk mengukur tingkat kesesuaian pada dimensi kepedulian penulis akan memberikan satu contoh pada atribut pernyataan nomor 16 pada dimensi kepedulian, berikut merupakan hasil yang akan didapat.

Diketahui: $\quad \mathrm{Xi}=77$

$$
\mathrm{Yi}=87
$$

Ditanya: Tki (TingkatKesesuaian)...? 
Dapat dihitung dengan menggunakan rumus:

$$
\begin{gathered}
\text { TKI }=\frac{77}{87} \times 100 \% \\
\text { TKI }=\frac{77}{87} \times 100 \% \\
\text { TKI }=88,51 \%
\end{gathered}
$$

Hasil diatas merupakan hasil perhitungan untuk mencari tingkat kesesuaian dimensi jaminan pada atribut pernyataan no 16, untuk menghitung tingkat kesesuaian pada atribut selanjutnya seperti pada atribut pernyataan nomor 17, 18, 19, dan 20 dapat dihitung dengan menggunakan cara yang sama.

Tabel dibawah ini merupakan hasil dari tingkat kesesuaian seluruh atribut pernyataan pada dimensi kualitas pelayanan kepedulian (empathy)

\section{Tabel 5. Hasil Tingkat Kesesuaian Empati (Empathy)}

\begin{tabular}{ccccc}
\hline No & $\begin{array}{c}\text { Tingkat } \\
\text { Kinerja }(\mathbf{X})\end{array}$ & $\begin{array}{c}\text { Tingkat } \\
\text { Harapan }(\mathbf{Y})\end{array}$ & $\begin{array}{c}\text { Tingkat Kesesuaian } \\
\mathbf{( T K )}(\boldsymbol{\%})\end{array}$ & $\begin{array}{c}\text { Kinerja Kualitas } \\
\text { Pelayanan }\end{array}$ \\
\hline 16 & 77 & 87 & 88,51 & Sangat Baik \\
\hline 17 & 77 & 88 & 87,5 & Sangat Baik \\
\hline 18 & 77 & 85 & 90,59 & Sangat Baik \\
\hline 19 & 75 & 83 & 90,36 & Sangat Baik \\
\hline 20 & 76 & 84 & 90,48 & Sangat Baik \\
\hline
\end{tabular}

Hasil penelitian penulis dari 24 responden yang ada terhadap dimensi empati (empathy) pada nasabah PT. SSI Medan dengan pernyataan no 16 (memberikan perhatian dan penyelesaian masalah dalam waktu cepat) tingkat kinerja memperoleh hasil sebesar 77 dan tingkat harapan sebesar 87 sehingga menghasilkan tingkat kesesuaian sebesar $88,51 \%$ yang artinya sangat baik bagi perusahaan dan konsumen puas.

Pada pernyataan no.17 (bertanggung jawab terhadap keamanan mesin ATM) tingkat kinerja yang dihasilkan sebesar 77 dan tingkat harapan sebesar 88, menghasilkan tingkat kesesuaian sebesar $87,5 \%$ berarti dalam dimensi ini kinerja perusahaan sudah sangat baik.

Pernyataan no.18 (pelayanan yang adil ke setiap pemberi kerja) pada tingkat kinerja dihasilkan nilai sebesar 77 sedangkan pada tingkat harapan sebesar 85 dan menghasilkan tingkat kesesuaian sebesar 90,59\% dalam dimensi ini berarti kinerja perusahaan dalam kualitas pelayanannya sudah sangat baik sehingga konsumen merasa puas karena harapannya sudah terpenuhi.

Pernyataan no.19 (penentuan lokasi yang strategis untuk lokasi mesin ATM) pada tingkat kinerja dihasilkan nilai sebesar 75 sedangkan pada tingkat harapan sebesar 83 dan menghasilkan tingkat kesesuaian sebesar $90,36 \%$ dalam dimensi ini berarti kinerja perusahaan dalam kualitas pelayanannya sudah sangat baik sehingga konsumen merasa puas karena harapannya sudah terpenuhi.

Selanjutnya pernyataan no.20 (Up date informasi teknologi monitoring ATM) tingkat kinerja yang dihasilkan sebesar 76 dan tingkat harapan sebesar 84, menghasilkan tingkat kesesuaian sebesar $90,48 \%$ berarti dalam dimensi ini kinerja perusahaan sudah sangat baik karena berada di antara $81 \%-100 \%$.

\section{Tingkat Kepuasan Konsumen Pada Dimensi Jaminan (Assurance)}

Dimensi jaminan meliputi kemampuan karyawan atas pengetahuan terhadap produk secara tepat, kualitas terhadap keramah-tamahan, perhatian dan kesopanan dalam memberikan 
keamanan didalam memanfaatkan jasa yang ditawarkan dan kemampuan dalam menanamkan kepercayaan pelanggan terhadap perusahaan.

Untuk mengukur tingkat kesesuaian pada dimensi jaminan penulis akan memberikan satu contoh pada atribut pernyataan nomor 21 pada dimensi jaminan, berikut merupakan hasil yang akan didapat.

Diketahui: $\quad \mathrm{Xi}=79$

$$
\mathrm{Yi}=86
$$

Ditanya: Tki (Tingkat Kesesuaian)...?

Dapat dihitung dengan menggunakan rumus:

$$
\begin{gathered}
\mathrm{TKI}=\frac{\mathrm{Xi}}{\mathrm{Yi}} \times 100 \% \\
\mathrm{TKI}=\frac{79}{86} \times 100 \% \\
\mathrm{TKI}=91,86 \%
\end{gathered}
$$

Hasil diatas merupakan hasil perhitungan untuk mencari tingkat kesesuaian dimensi jaminan pada atribut pernyataan no 21, untuk menghitung tingkat kesesuaian pada atribut selanjutnya seperti pada atribut pernyataan nomor 22, 23, 24, 25 dapat dihitung dengan menggunakan cara yang sama. Tabel dibawah ini merupakan hasil dari tingkat kesesuaian seluruh atribut pernyataan pada dimensi kualitas pelayanan jaminan (assurance).

Tabel 6. Hasil Tingkat Kesesuaian Jaminan (Assurance)

\begin{tabular}{ccccc} 
No & $\begin{array}{c}\text { Tingkat } \\
\text { Kinerja (X) }\end{array}$ & $\begin{array}{c}\text { Tingkat } \\
\text { Harapan }(\mathbf{Y})\end{array}$ & $\begin{array}{c}\text { Tingkat Kesesuaian } \\
\text { (TK) }(\boldsymbol{\%})\end{array}$ & $\begin{array}{c}\text { Kinerja Kualitas } \\
\text { Pelayanan }\end{array}$ \\
\hline 21 & 79 & 88 & 91,86 & Sangat Baik \\
\hline 22 & 72 & 87 & 82,76 & Sangat Baik \\
\hline 23 & 78 & 87 & 89,66 & Sangat Baik \\
\hline 24 & 82 & 86 & 95,35 & Sangat Baik \\
\hline 25 & 79 & 85 & 92,94 & Sangat Baik \\
\hline
\end{tabular}

Hasil penelitian penulisdari 24 responden yang ada terhadap dimensi jaminan (assurance) pada butir pernyataan 21 dengan pernyataan (pencapaian target service level agreement) tingkat kinerja memperoleh hasil sebesar 79 dan tingkat harapan sebesar 88 sehingga menghasilkan tingkat kesesuaian sebesar $91,86 \%$ yang artinya masuk dalam kategori kinerja kualitas pelayanan yang sangat baik.

Pada pernyataan no.22 (stock spare part mesin ATM cukup) tingkat kinerja yang dihasilkan sebesar 72 dan tingkat harapan sebesar 87, menghasilkan tingkat kesesuaian sebesar $82,76 \%$ berarti dalam dimensi ini kinerja perusahaan sudah sangat baik.

Pernyataan no.23 (ketersediaan pengamanan bersenjata api) pada tingkat kinerja dihasilkan nilai sebesar 78 sedangkan pada tingkat harapan sebesar 87 dan menghasilkan tingkat kesesuaian sebesar 89,66\% dalam dimensi ini berarti kinerja perusahaan dalam kualitas pelayanannya sudah sangat baik sehingga konsumen merasa puas karena harapannya sudah terpenuhi.

Selanjutnya pernyataan no.24 (kejujuran pegawai dalam melakukan setiap kegiatan kerja) tingkat kinerja yang dihasilkan sebesar 82 dan tingkat harapan sebesar 86, menghasilkan tingkat kesesuaian sebesar $95,35 \%$ berarti dalam dimensi ini kinerja perusahaan sudah sangat baik karena berada di antara 81\%-100\%.

Yang terakhir, yakni pernyataan no. 25 (melaporkan setiap kegiatan operasional secara konsisten) tingkat kinerja yang dihasilkan sebesar 79 dan tingkat harapan sebesar 85, 
menghasilkan tingkat kesesuaian sebesar $92,94 \%$ berarti dalam dimensi ini kinerja perusahaan sudah sangat baik karena berada di antara $81 \%-100 \%$

Setelah mendapatkan hasil tingkat kesesuaian langkah yang harus dikerjakan yaitu mencari Skor (total kinerja dan harapan) untuk menemukan titik potong sumbu $\mathrm{X}$ dan sumbu Y.

Dari hasil diatas dapat dilihat bahwa untuk mencari sumbu $\mathrm{X}$ dan sumbu $\mathrm{Y}$ Dapat dilakukan dengan rumus:

$$
\mathrm{X}=\frac{\sum \mathrm{Xi}}{\mathrm{k}}
$$

$$
\mathrm{Y}=\frac{\sum \mathrm{Yi}}{\mathrm{k}}
$$

Dimana :

$\mathrm{X}=$ Skor rata-rata tingkat persepsi nasabah

$\mathrm{Y}=$ Skor rata-rata tingkat harapan nasabah

$\mathrm{Xi}=$ Skor penilaian persepsi nasabah

$\mathrm{Yi}=$ Skor penilaian harapan nasabah

$\mathrm{k}=$ Jumlah atribut pernyataan

Penjelasan analisis faktor-faktor dimensi kualitas pelayanan pada PT. SSI MEDAN menggunakan 5 dimensi kualitas pelayanan yaitu bukti langsung (tangible), keandalan (reability), daya tanggap (responsiveness), jaminan (assurance), dan kepedulian (empathy), yang dikaitkan dengan analisis 4 kuadran dalam Diagram Kartesius (Rosadi Ruslan2013 hal.271).

\section{PEMBAHASAN}

Kepuasan pelanggan adalah perasaan konsumen setelah merasakan antara apa yang sudah dia terima dengan harapan yang diinginkan. Pelanggan akan merasa puas jika nilai yang diberikan oleh produk atau jasa memuaskan pelanggan dalam waktu yang lama (Arianty, 2015). Penelitian ini bertujuan untuk mengukur tingkat kepuasan nasabah Bank dengan menggunakan uji validitas dan uji reabilitas dan dengan menggunakan teknik Analisis Importance Performace.

Uji validitas digunakan untuk menguji apakah instrument yang dipakai cukup layak digunakan sehingga mampu menghasilkan data yang akurat sesuai dengan tujuan pengukurannya. Sedangkan uji reabiltas bertujuan untuk melihat apakah instrument penelitian merupakan instrument yang handal dan dapat dipercaya. Setelah dilakukan pengujian terhadap uji validitas dan uji reabilitas menyatakan bahwa instrument pernyataan dinyatakan layak untuk dilakukan sebagai data untuk melanjutkan penelitian.

Pada teknik Analisis Importance Performance digunakan untuk mengukur tingkat kepuasan pelanggan berdasarkan 4 dimensi kualitas pelayanan yaitu keandalan (reability), daya tanggap (responsiveness), empati (empathy) serta jaminan (assurance).

Ada 4 kuadran yang digunakan untuk mengukur tingkat kepuasan pelanggan pada teknik Analisis Importance Performace yaitu kuadran 1 (prioritas utama), atribut pada kuadran ini dianggap sangat penting oleh nasabah tetapi pelayanannya tidak memuaskan sehingga perusahaan harus meningkatkan kualitas pelayanannya. Kuadran 2 (pertahankan prestasi), atribut pada kuadran ini dianggap sangat penting oleh nasabah dan pelayanannya sangat memuaskan, sehingga perusahaan harus mempertahankan kualitas pelayanannya. Kuadran 3 (prioritas rendah), atribut pada kuadran ini dianggap tidak penting oleh pelanggan dan pelayanannya kurang memuaskan. Yang terakhir adalah kuadran 4 (berlebihan), atribut pada kuadran ini dianggap tidak penting oleh pelanggan tetapi pelayanannya memuaskan. 
Berikut merupakan hasil pembahasan dari kuadran pelayanan pada teknik Analisis Importance Performace untuk mengukur tingkat kepuasan pelanggan berdasarkan 4 dimensi kualitas pelyanan keandalan (reability), daya tanggap (responsiveness), empati (empathy) serta jaminan (assurance)

\section{Kuadran I (Prioritas Utama)}

Pada kuadran ini menunjukan faktor-faktor tingkat kepuasan nasabah dan penanganannya perlu diprioritaskan lagi, karena tingkat harapan pelanggan tinggi sedangkan tingkat persepsi masih rendah. Ada 4 butir yang masih harus menjadi prioritas utama karena berada di kuadran ini, yaitu atribut no 5, no 4, no 2, no 3, dan no 15. Hal ini mengisyaratkan bahwa atribut kenyataan (tangibles) harus menjadi perhatian utama. Dikarenakan dari 5 butir, 4 diantaranya berada di kuadran $1(2,3,4,5)$.

\section{Kuadran II (Pertahankan Prestasi)}

Pada kuadran ini menunjukkan bahwa faktor-faktor tingkat kepuasan pelanggan pada kuadran ini perlu dipertahankan. Ada 8 butir yang berada di kuadran 2, yaitu butir no 1, 7, 8, 10, 11, 13, 14, dan 17. Dari sini dapat dilihat bahwa atribut kehandalan sudah cukup baik dikarenakan dari total 5 butir, 3 diantaranya berada di kuadran 2, begitupun juga atribut daya tanggap (responsiveness).

\section{Kuadran III (Prioritas Rendah)}

Posisi pada kuadran ini, menunjukkan faktor-faktor tingkat kualitas pelayanan pada kuadran ini masih dianggap rendah bagi pelanggan, karena tingkatkinerjanya rendah sedangkan harapan pelanggan tinggi. Ada 4 butir yang berada di kuadran 3 (prioritas rendah), yaitu butir no 9, 19, 20, dan 22. Dari sini terlihat bahwa atribut kehandalan memiliki satu butir yang berada di kuadran ini, begitu pula dengan atribut jaminan (assurance). Sedangkan empati (empathy) memiliki dua butir.

\section{Kuadran IV (Berlebihan)}

Pada kuadran ini menunjukkan bahwa faktor-faktor tingkat kualitas pelayanan pada kuadran ini masih dianggap rendah bagi pelanggan karena kuadran ini dianggap sebagai kuadran yang berlebihan dengan tingkat harapan pelanggan rendah sedangkan tingkat kinerjanya tinggi. Ada 7 butir pernyataan yang berada di kuadran 4 ini, yaitu butir pernyataan no $6,12,16,18,21,23$, dan 25 . Atribut kehandalan (reability) memiliki satu butir pernyataan yang dianggap berlebihan, begitu pula dengan daya tanggap (responsiveness). Atribut empati (empathy) memiliki 2 butir pernyataan yang berada di kuadran 4 (berlebihan) yaitu butir pernyataan no 16 dan 18. Dari seluruh butir yang berada di kuadran 4, mayoritas dimiliki oleh atribut jaminan (assurance) karena tiga dari lima butir yang berada di atribut ini berada di kuadran 4.

\section{KESIMPULAN}

Berdasarkan hasil penelitian dan pembahasan yang telah diuraikan, dapat ditarik kesimpulan ada 5 atribut pernyataan yang berada di kuadran 1 (prioritas utama), yakni pernyataan nomor $2,3,4,5$, dan 15 . Ada 8 atribut pernyataan yang berada di kuadran 2 (pertahankan prestasi), yakni pernyataan nomor 1, 7, 8, 10,11, 13, 14, dan 17. Ada empat butir pernyataan yang berada di kuadran 3 (prioritas rendah), yaitu butir pernyataan nomor 9, 19, 20, dan 22. Ada tujuh butir pernyataan yang berada di kuadran 4 (berlebihan) yaitu butir pernyataan nomor $6,12,16,18,21,23$, dan 25 . Berdasarkan kesimpulan diatas maka saran-saran yang 
dapat diberikan yaitu PT. SSI MEDAN hendaknya memperhatikan hal-hal yang dinilai masih lemah. Setidaknya ada lima poin penting yang harus dilakukan PT. SSI MEDAN untuk meningkatkan kepuasan nasabahnya, yaitu meningkatkan lagi ketersediaan spare part karena kinerja masih dinilai lebih rendah dibanding harapan konsumen. Selain itu, PT. SSI MEDAN juga hendaknya meningkatkan standard sarana prasana operasionalnya. Hal yang juga banyak dikeluhkan oleh nasabah adalah keamanan kunci brankas ATM. Yang harus ditingkatkan juga demi perbaikan kepuasan nasabah adalah waktu yang dibutuhkan untuk penyelesaian permasalahan hendaknya lebih dipercepat. Selain yang harus ditingkatkan, ada beberapa hal yang sudah baik, walaupun ekspektasi tinggi, tetapi perusahaan mampu memberikan kinerja yang bagus sehingga hal-hal ini harus terus dipertahankan oleh PT. SSI MEDAN demi tercapainya kepuasan. Hal-hal tersebut adalah kepastian akan menyalanya ATM online selama 24 jam penuh, ketepatan dalam menyelesaikan problem ATM, kecepatan respon, daya tanggap karyawan dalam hal-hal operasional mesin ATM, kemmapuan karyawan berkomunikasi dengan pemberi kerja, serta tanggung jawab terhadap keamanan mesin ATM.

\section{DAFTAR PUSTAKA}

Arianty, N. (2015). Pengaruh Kualitas Pelayanan Dan Kualitas Produk Terhadap Kepuasan Konsumen Handphone Samsung. Jurnal Ilmiah Manajemen Dan Bisnis, 16(2), 68-81. https://doi.org/10.30596/jimb.v16i2.958

Azhar, M. E., \& Jufrizen, J. (2017). The Analysis of The Tourist Loyalty Determinant In the Area of Toba Lake. International Journal of Recent Scientific Research, 8(10), 2082620832.

Azhar, M. E., Jufrizen, J., Prayogi, M. A., \& Sari, M. (2018). The Role of Marketing Mix and Service Quality on Tourist Satisfaction and Loyalty at Samosir. Journal of Tourism, (26).

Gultom, D. K., \& Jufrizen, J. (2016). Nilai Nilai Islam sebagai Variabel Moderating pada Pengaruh Bauran Pemasaran Jasa dan Kualitas Pelayanan Terhadap Kepuasan Mahasiswa (Studi di Fakultas Ekonomi Universitas Islam Swasta di Kota Medan). Jurnal Ilmiah Maksitek, 1(1), 35-47.

Isnaeni, H. F. (2019). Mesin ATM Pertama di Indonesia.

Jasfar, F., \& Kristaung, R. (2012). Sinergi Pemasaran Jasa Ritel. Jakarta: Universitas Trisakti Jakarta.

Kartajaya, H. (2009). Kompas 100 Corporate Marketing Cases. Jakarta: PT Gramedia Pustaka Utama.

Kotler, P. (2009). Manajemen Pemasaran. Jakarta: Erlangga.

Kotler, P., \& Amstrong, G. (2012). Principles of Marketing. New Jersey: Pearson Prentice Hall. Lovelock, C. H., \& Wright, L. K. (2010). Manajemen Pemasaran Jasa. Jakarta: PT. Indeks.

Lupiyoadi, R., \& Hamdani, A. (2006). Manajemen Pemasaran Jasa. (2, Ed.). Jakarta: Salemba Empat.

Mulyani, S. (2003). Dampak Kualitas Jasa Pelayanan Terhadap Perilaku Konsumen. Jurnal Gemawisata, 2(1).

Parasuraman, A. P., Zeithaml, V. A., \& Berry, L. L. (1988). "SERVQUAL: A Multiple-Item Scale for Measuring Consumer Perceptions of Service Quality. Journal of Retailing, 64(1), 12-40.

Radiman, R., Gunawan, A., Wahyuni, S. F., \& Jufrizen, J. (2018). The Effect of Marketing Mix, Service Quality, Islamic Values and Institutional Image on Students' Satisfaction and Loyalty. Expert Journal of Marketing, 6(2), 95-105.

Sangadji, E. M., \& Sopiah. (2013). Perilaku Konsumen: Pendekatan Praktis Disertai Himpunan Jurnal Penelitian. Yogyakarta: Andi. 
ISSN 2623-2634 (online)

DOI: https://doi.org/10.30596/maneggio.v2i2.3778

Tjiptono, F. (2006). Manajemen Jasa. Yogyakarta: Andi Offset.

Tjiptono, F., \& Chandra, G. (2011). Service, Quality \& Statisfaction (3rd ed.). Yogyakarta: Andi Offset.

Tjiptono, F., \& Chandra, G. (2012). Service, Quality \& Satisfaction (2nd ed.). Yogyakarta: Andi Offset. 